\title{
THEORETICAL ANALYSIS OF THE SOCIAL PROTECTION AND RELATED CONCEPTS
}

\author{
Vardanyan, Yevgine
}

\begin{abstract}
Social protection is a concept widely used in many disciplines and from different perspectives. Those are some of the main reasons why it still has no concrete and overall definition. The same situation exists related to the other concepts closely connected to social protection. Those are usually used for describing the social protection system in one or another country. But still, the concepts like social welfare, social policy, and social insurance are, also need to be defined and described in the terms of the main links with "social protection" concept.

The article is aimed to analyzing the concepts that are widely used in social protection sphere, but which in many cases are applied in different situations and with different meanings. It is also directed towards describing the main links between the social protection and closely related to it concepts, like social policy, social welfare, social insurance and social services are.

The article is based on theoretical overview of main approaches and theories created for those concepts' definition.
\end{abstract}

Keywords: social protection, social welfare, social policy, social protection, situation and JEL: Z31 meanings, policy, social services 


\section{Theoretical Overview: Social Protection}

Social protection is very much a creation of the twentieth century and it has become the object of the close attention of the researchers and scientists only recently.

The form and extent of social protection differ greatly between nations but the fact that nearly all countries, differing greatly in their economic, social and cultural circumstances, have introduced social protection is itself remarkable (James Midgley, David Piachaud, 2013).

Still, there is no overall and inclusive version of how social protection can be defined. That is caused by the fact that modern countries have developed different practices and experiences, for responding to the social problems they face, and also because social protection is studied by different disciplines, like economics, sociology, public administration, social work, etc. So we can assume that there are many approaches of defining and explaining social protection. Some view it as a policy framework employed to address poverty and vulnerability (Armando Barrientos, 2013), other specialists consider that social protection is concerned with protecting and helping those who are poor and vulnerable, such as children, women, older people, people with disabilities, the displaced, the unemployed, and the sick (Harvey, Holmes, Slater, Martin, 2007). The other approach suggests wider meaning of social protection connecting it to not only the reduction of poverty and vulnerability but also emphasizing its important role and influence in socio-economic security, social inclusion and cohesion (A. Bonilla Garcia and J.V. Gruat, 2003). It impacts have also been seen as enhancing economic and productive capacity of poor households to cope with, respond to and withstand natural and human-induced crises (UN, 2017). Analyzing the main approaches which are developed for presenting the definition of social protection, we can assume that some suggest very narrow understanding of it making similar to social welfare (social support), that is the provision of material and nonmaterial assistance to the vulnerable groups of population, and the other approaches tend to see social protection as much wider concept closely related to the high level of well-being and adequate functioning of different groups of population. So on the one the hand, social protection can meet the essential needs of human survival by ensuring that all men and women have basic social and economic security. At the time, it can play a more far-reaching role in enhancing the quality of life of individuals and societies by developing and unleashing human potential, facilitating structural change, increasing stability, advancing social justice cohesion, and promoting economic dynamism (A. Bonilla Garcia, J.V. Gruat, 2003).

Though we share the opinion that all those approaches have the right to be taken into account while defining social protection, we also think that there should be at least one acceptable "solution" for having more inclusive, but at the same time concrete definition of the social protection. That can be a definition which connects the social 
protection to the procedures of overcoming social problems and preventing different social risks, like the poverty, unemployment, health or educational problems are. These types of definitions allow seeing the role and importance of social protection not only in responding to the different social problems, but also in making conditions for long-time prevention of difficult life situations. We also suggest that the role of the social protection in the realization and protection of the human rights, especially of social rights. This function of social protection system should also be emphasized. So, taking into account the suggestions mentioned above, we can offer to use the definitions of social protection, which emphasizes its role in preventing social risks, providing social assistance in overcoming social problems and creating the necessary prerequisites for realizing or protecting the rights of population or different groups of it. One of these kinds of definition can be the following:

Social protection is all public and private initiatives that provide social assistance to those groups of population that have been occurred in difficult life situations, which they are not able to overcome on their own. It is also directed towards preventing social risks by enhancing the individual or group (including family and community) capacities and promoting the development of the necessary social environment for that.

Social protection also considers the measures and convenient actions directed to the protection of the social rights of population.

Social protection is closely related to other different concepts, like social security, social welfare, social policy and social insurance are. The concrete identification of the links of those concepts with social protection is also very necessary, because it will bring clarity in the categorical system of social sciences.

\section{Social Protection and Social Security}

Starting from the connections of social protection and social security concepts, we should mention that although the term social security is derived from a common Latin root, it has been defined in different ways by different experts. Some define social security narrowly as the provision by the state of monetary benefits to persons who experience contingencies specifies by the statute, while others interpret it broadly to encompass a variety of programs and services provided by both public and nongovernmental organizations. These differences are not only a manifestation of academic preference, but reflect real variations in the programs provided by social security agencies around the world (J. Midgley, 1997). In some countries such as the United States, social security refers to the insurance funded retirement, invalidity and survivor's benefits provided in terms of the 1935 Social Security Act. In Britain, the term social security includes social assistance, unemployment payments and child 
benefits. In many Latin American countries the provision of medical services forms an integral part of the social security system. In some Latin American countries, social security also includes vocational training, youth activities and recreational and cultural programs (J. Midgley, 1997).

Still, all those definitions have clear similarity; it is that social protection is considered a wider concept, than social security is. Based on it social security can be viewed as a form of social protection which have almost the same meaning and the aim.

So from this point of view social protection includes social security with its forms and programs and it is implemented mostly on behalf of social security system.

The International Labor Organization has sought to standardize the meaning of social security and has suggested the following definition of it:

Social security is the protection which society provides for its members through a series of public measures against the economic and social distress that otherwise would be caused by the stoppage or substantial reduction of earnings resulting from sickness, maternity, employment injury, invalidity and death, provision of medical care, and the provision of subsidies for families with children (ILO, 1984).

Analyzing this definition we can conclude, that it identifies social security and social insurance as synonymous.

But there is also another opinion about the links between social security and social protection and that opinion is also very widespread in the professional literature. This is another approach which defines social security as situation of social, economic, political stability and a source of the individual and social development (A. Skifskaya, 2014, M. Liga, 2013).

Trying to reveal the main links of the two concepts like social protection and social security are, we can suggest two main ways for understanding those connections.

First, we can say that if the social security is viewed in a narrow way and is considered as a variety of programs and social services provided by both public and nongovernmental organizations, then social protection can be explained as a wider concept, which includes also social security programs. But if we take into account the other approach of explaining social security, which considers it as a situation, when the socio-economic stability is achieved, then of course, it can be viewed as a wider notion than social protection is. Even more, in that case social security becomes something like a goal or a main aim for the social protection system in any country.

\section{Social Protection and Social Policy}

It is really very important to study the connections of social protection with another very important concept like social policy is. The issue is the same. There is no clear 
way or concrete approach for explaining the connections of those two concepts. And that is conditioned by the fact, the social policy, as well as both social security and social protection is defined in very different ways.

So social policy is not an easy area or discipline to be defined. It is usually defined as a term to denote a set of policies and practices concerned with promoting social welfare and wellbeing. This definition has most usually been associated with the provision of social welfare through institutions of the state. Social policy is also viewed as an interdisciplinary and applied subject concerned with the analysis of societies' responses to social need (London School of Economics, 2015). As we can conclude from those definitions, social policy presents the mechanism which the society implies for meeting the social need. Social policy is also described as a public policy and practice area in the spheres of health care, human services, criminal justice, inequality, education and labor (Malcolm Wiener Center, 2015). Social policy might also be described as actions that affect the well-being of members of a society through shaping the distribution of and access to goods and resources in the society (Christine Cheyne, Mike O'Brian, 2005). All those definitions describe social policy as a mechanism for the implementation of the goals of social protection, which consists of the appropriate policies and programs. At the same time there are several other approaches which define social policy as in a broader way, saying that: "At its broadest, social policy could corporate all governmental policy that has, by definition, a social dimension" (Amanda Coffey, 2004). For analyzing the way by which social policy is related or connected to social protection concept, we can mention that those connections or links depend on what approach we choose for defining those concepts. If we consider social protection as a set of policies directed towards meeting social need, then we can assume that it can be viewed as a mechanism for providing social protection to the members of the society. But if we define it as a policy implemented by the governmental or nongovernmental organizations in the social sphere, then, of course, we can surely say that in that case social protection system is designed for accomplishing the goals in the social sphere of the society.

\section{Social Protection and Social Welfare}

Another important concept that should also be defined and analyzed in the frames of social protection studies is the social welfare. That is a term that doesn't have clear meaning and concrete explanation as well. The way the social welfare is defined depends on the reasons of its definition. In some cases it is considered to be a situation, which is more concerned with the quality of life that includes factors such as the quality of the environment (air, soil, water), level of crime, extent of drug 
abuse, availability of essential social services, as well as religious and spiritual aspects of life (http://www.businessdictionary.com/definition/social-welfare.html, 2019).

Social welfare is also defined as a system of organized or private social services for the assistance of disadvantaged groups (Merriam-Webster dictionary, 2019). In this case it is seen as a part of social protection system, as a subsystem which provides assistance to needy individuals and families (https://www.investopedia.com/terms/s/ social-welfare-system.asp, 2019).

Meanwhile, social welfare is also defined as a social changes designed to promote the well-being of the population as a whole in conjunction with a dynamic process of economic development. From that point of view social welfare is seen as a whole system directed towards making necessary conditions for high level of life quality and welfare life. In this case social welfare can even be viewed a system equal to social protection. But if we take into account international advanced practice, we will see that although the types and amount of welfare available to individuals and families vary depending on the country, state or the region, they are all connected with the same aim, which is social assistance provision to the families and individuals who need that assistance to be provided in a need-based and professionalized way.

\section{Social Protection and Social Insurance}

The other concept that should be analyzed because it's close relatedness to social protection is social insurance. The last is mainly defined as a type of social protection and in fact the two terms sometimes used interchangeably. The reasons for that are the definitions which sometimes give the same characterization to both of those concepts. Social insurance is defined as a protection of the individuals against economic hazards (such as unemployment old age, or disability) in which the government participates or enforces the participation of employers and effected individuals (Merriam Webster Dictionary, 2019). In this sense it is also considered as a same term, like social security is. For specifying social insurance and emphasizing its main differences from social protection we can mention that social insurance is also defined as a form of social protection which is directed towards the inclusion of groups currently or possibly in the future not participating in insured employment. Entitlement to social insurance benefit is neither based on need nor coffered as a social right per se, but is conditional on compulsory contributions to one (or several) social insurance funds while employment (Jochen Clasen, 1997). Thus, participation in paid work is generally the key criterion for social insurance.

The benefits, their sizes and complementary schemes for employees vary greatly from one country to another and dependent on the main characteristics of the 
social protection system of that country. Nevertheless, the standard of protection and complementary schemes tend to play an important role in achieving real improvement in material living standards for many people and at the same time contributing to the preservation of existing social structures (Jochen Clasen, 1997).

\section{References}

[1.] A. Bonilla Garcia - J. V. Gruat (2003): Social Protection: A Life Cycle Continuum Investment for Social Justice. Poverty Reduction and Sustainable Development, ILO, Geneva.

[2.] Amanda Coffey (2004): Reconceptualizing Social Policy: Sociological Perspectives on Contemporary Social Policy. UK.

[3.] Armando Barrientos (2013): Social Assistance in Developing Countries. Cambridge University Press, UK, 2013.

[4.] Bujdosó Zoltán - Dávid Lóránt - Remenyik Bulcsú - Tóth Géza (2011): Connection between tourism and regional development on the HungarianCroatian border. Central European Regional Policy And Human Geography 1: 2 pp. 27-40., 14 p.

[5.] Christine Cheyne - Mike O’Brian - Michel Belgrave (2005): Social Policy in New Zealand: A Critical Introduction.

[6.] Harvey, Holmes - Slater, Martin (2007): Social Protection in Fragile States.

[7.] Integrated Social Services in Europe: Report, Council of Europe, 2007.

[8.] International Labor Standards on Social Security, 1952.

[9.] Introduction to Social Security, ILO, 1984.

[10.] James Midgley (1997): Social Welfare in Global Context. Sage Publications, London.

[11.] James Midgley - David Piachaud (2013): Social Protection, Economic Growth and Social Change: Goals, Issues and Trajectories in China, India, Brazil and South Africa.

[12.] Jochen Clasen (1997): Social Insurance in Europe. The Policy Press, Bristol.

[13.] Social Insurance and Social Protection, International Labor Organization, International Labor Office, International Labor Conference, 1993.

[14.] Social Policy, London School of Economics, UK. 
[15.] Social Policy, Malcolm Wiener Center, 2015.

[16.] Social Protection and Resilience: Supporting Livelihoods in Protracted Crises and in Fragile and Humanitarian Contexts, UN, 2017.

[17.] Business Dictionary, http://www.businessdictionary.com/definition/socialwelfare.html, 2019,

[18.] Encyclopedia Britannica, https://www.britannica.com/topic/social-service, 2019.

[19.] Merriam-Webster Dictionary, https://www.merriam-webster.com/dictionary/ social\%20welfare, 2019.

[20.] Merriam-Webster Dictionary, https://www.merriam-webster.com/dictionary/ social\%20insurance, 2019.

\section{Author}

\section{Yevgine Vardanyan}

$\mathrm{PhD}$ in Sociology

Yerevan State University, Faculty of Sociology

1 Alek Manukyan St, Yerevan 0025

Department of Social Work and Social Technologies

yevginevardanyan@gmail.com 